FESIEE Fundación Emilio Soldevilla para la Investigación y Desarrollo
de la Economía de la Empresa journal homepage: http://www.ehu.eus/cuadernosdegestion/revista/es/

ISSN: 1131-6837 / e-ISSN: 1988-2157

\title{
Innovation management in small and medium enterprises: A bibliometric analysis approach between 1985 and 2019
}

\section{Gestión de la innovación en la pequeña y mediana empresa: un enfoque de análisis bibliométrico entre 1985 y 2019}

Denisse Liliana Ballardo Cárdenas ${ }^{\mathrm{a}}$, Ramón Martínez Huerta ${ }^{\mathrm{b}}$, Ernesto León Castro ${ }^{\star}$, Kenia Caroly Sánchez Valenzuela ${ }^{\mathrm{c}}$

a Universidad Autónoma de Occidente (UAdeO). Blvd. Lola Beltrán and Blvd. Rolando Arjona, 4 de marzo, Z.C. 80020 Culiacán Rosales, Sinaloa, México - denisse. ballardo@uadeo.mx-https://orcid.org/0000-0002-2363-7376

${ }^{b}$ Universidad Autónoma de Occidente (UAdeO). Blvd. Lola Beltrán and Blvd. Rolando Arjona, 4 de marzo, Z.C. 80020 Culiacán Rosales, Sinaloa, México - ramon. martinez@uadeo.mx-https://orcid.org/0000-0001-7934-4217

c Universidad Autónoma de Occidente (UAdeO). Blvd. Lola Beltrán and Blvd. Rolando Arjona, 4 de marzo, Z.C. 80020 Culiacán Rosales, Sinaloa, México - kenia. sanchez@uadeo.mx-https://orcid.org/0000-0001-9605-625X

* Corresponding author: Universidad Católica de la Santísima Concepcion. Av. Alonso de Ribera 2850, Concepción, Bío Bío, Chile - eleon@ucsc.cl - https://orcid. org/0000-0002-0087-2226

A R T I C L E I N F O

Received 29 June 2021 ,

Accepted 23 December 2021

Available online 4 March 2022

DOI: $10.5295 /$ cdg.211551el

JEL: A14, O30

\begin{abstract}
A B S T R A C T
Many changes have come over the business with the onset of globalization and the digitization of the economy, including the last two years. In addition, relevant changes have been caused by the COVID-19 pandemic, demonstrating the relevance of innovation management (IM) within organizations as a process to face these new realities. This article aims to present the main contributions on innovation management in small- and medium-sized enterprises (IM in SMEs). To determine the state-of-the-art innovation techniques, the study systematically reviews articles related to this subject using a bibliometric study approach between 1985 and 2019 using the Web of Science (WoS) database. The study analyzes and presents the most cited articles, the main authors, institutions, countries, and the most productive journals. Additionally, VOSviewer was used to provide a more in-depth analysis of the data obtained from the search. Among the main results, it is clear that the most productive universities and the most influential and productive authors are in the United States, leaving a relevant possibility of taking this analysis to different countries, mainly developing countries, to adjust adequate innovation processes according to the specific realities of each country.
\end{abstract}

Keywords: Innovation Management; Small and Medium Businesses; Bibliometric Analysis; VOSviewer.

\section{R E S U M E N}

Muchos cambios empresariales se han generado con la globalización y la digitalización de la economía, incluyendo estos últimos 2 años se han generado cambios relevantes derivados de la pandemia Covid 19, demostrando la relevancia de la gestión de la innovación dentro de las organizaciones, como proceso para afrontar estas nuevas realidades. Este artículo tiene como objetivo presentar las principales aportaciones sobre el tema de la gestión de la innovación en la pequeña y mediana empresa (IM in SME). Para conocer el estado del arte del tema, el estudio revisa sistemáticamente artículos relacionados con este tema a través de un enfoque de estudio bibliométrico entre 1985 y 2019 utilizando bases de datos de Web of Science (WoS). El estudio analiza y presenta los artículos más citados, los principales autores, instituciones, países y las revistas más productivas. Además, se utilizó el software VOSviewer para proporcionar un análisis más profundo de los datos obtenidos de la búsqueda. Entre los principales resultados, está claro que las universidades más productivas, los autores más influyentes y productivos se encuentran en Estados Unidos dejando una posibilidad muy relevante de llevar este análisis a diferentes países, principalmente países en vías de desarrollo, para ajustar procesos de innovación adecuados de acuerdo con las realidades específicas de cada país.

Palabras clave: Gestión de Innovación; Pequeñas y Medianas Empresas; Análisis Bibliométrico; VOSviewer. 


\section{INTRODUCTION}

The business world states that the dynamic nature of most markets seems to explain why it is almost impossible to find an industry that is not involved in innovation (Hurley \& Hult, 1998). In this way, innovation stands out as one of the most effective ways of conducting business because it has been an important engine of growth and competitiveness for companies (OECD, 2005). Therefore, companies need to innovate, and it is possible through only a complex interaction of human, organizational, technological, and market elements. Innovation management (IM) seeks to understand and find better ways to manage these interactions for successful innovations.

IM seeks to understand and find better ways to manage these interactions for successful innovations. The literature on IM has constantly evolved (Keupp et al., 2012). In the study of IM, there is an interest focused on small- and medium-sized companies (SMEs) (Alfaro-García et al., 2017; Aragón-Sánchez \& SánchezMarín, 2005). SMEs introduce notable innovations (Keizer et al., 2001) that strengthen the position of the industry and generate profits above the market average (Porter, 1998) and are an important part of all countries' economies regarding their impact on economic growth, poverty reduction and job creation. However, SMEs are not only an important source of employment; they can also become a source of innovation and increased productivity (Herr \& Nettekoven, 2018). As a result, SMEs have become increasingly important players in the international business arena (Torres-Ortega et al., 2015). Notwithstanding, studies focused on SMEs are scarce and inconclusive (Solano Acosta et al., 2018).

The bibliometric study is considered the quantitative study of bibliographic material that can show a general image of a field of research (Merigó \& Yang, 2017). Additionally, it is a timely approach to examine the evolution of research domains, including topics and authors, based on disciplines' social, intellectual, and conceptual structures (Donthu et al., 2020).

For example, bibliometric analyses of specific journals (Byington et al., 2019; Merigó et al., 2018) and research areas such as e-health informatics (Kokol et al., 2018), corporate social responsibility (Bhattacharyya \& Verma, 2020), and fuzzy decision-making (Blanco-Mesa et al., 2017; Merigó et al., 2015) have been performed. Hence, this paper aims to provide useful information on scientific research publications about IM in SMEs from 1985 to 2019 through a bibliometric analysis.

Using VOSviewer software, the study uses a bibliometric approach to map authors, institutions, countries, and journals (van Eck \& Waltman, 2010). Among other results, this paper shows a growing field of study and that a considerable number of articles and citations are concentrated in different magazines. This paper continues as follows: Section 2 describes the research method by describing the bibliometric study, Section 3 presents the results of our bibliometric study, and Section 4 develops a graphical visualization of the results using VOSviewer software. Finally, Section 5 presents the main conclusions of the paper.

\section{THEORETICAL FRAMEWORK}

The concept of IM originates in Bruns and Stalker (1961) with an essentially sociological starting point, although it is related to industrial organization and business management.
IM includes research and development (R\&D) management and aspects such as the launch of new products and the study of the reasons for their success or failure (Escorsa \& Valls Pasola, 1997).

Addressing SMEs, IM studies are traditionally disconnected from technological innovation works. Therefore, some authors explore whether technological innovators benefit from introducing IM (Hervas-Oliver et al., 2015) and to what extent complementarities exist between IM and technological innovation (Volberda et al., 2013).

Furthermore, the managers of most companies know that carrying out innovative activities contributes to improving the competitiveness of their organizations and, consequently, to obtain higher incomes (Igartua \& Errasti, 2007). Similarly, companies become aware of the importance of innovation in their futures and the need to manage innovation to become highly competitive. Finally, they understand that innovation is key to the organisation's survival, as it is in public organizations that need to improve their services (Eveleens, 2010) or organizations that need to compete for market share or profits.

Therefore, IM in SMEs is an important instrument for the transformation of companies when the entire organization is ready to update and reform (Bilton \& Cummings, 2010) and can play a central role in the process of organizational change, facilitating organizational adaptation to the external environment and increasing the efficiency and effectiveness of internal processes (Walker et al., 2011).

\section{RESEARCH METHODOLOGY}

Currently, measuring the quality and quantity of scientific production is a necessity since almost every research assessment decision depends upon the scientific merits of the involved researchers (Gutiérrez-Salcedo et al., 2018). To do that, we introduce two main bibliometric procedures to analyze the impact of a research field and its scientific structures.

Particularly, this analysis is performed with the bibliographic search in which the Web of Science collection database is used (WoS). This database was previously used in academic research as the main source (Cancino et al., 2018; Rey-Martí et al., 2016; Rialti et al., 2019; van Nunen et al., 2018). In this sense, to search for articles that have focused on IM in SMEs, the research includes the following steps:

Step 1. The study uses "innovation management" and SME or "small and medium enterprise ${ }^{\star}$. This selection of keywords helps determine the study sample and considers the objective and criteria equivalent to innovation management in small and medium enterprises. The analysis considered any work available in WoS between 1985 and 2019 to capture as many possible combinations of terms related to IM in SMEs. This search finds 3,117 articles, which have become 3,055 studies by considering only articles, reviews, and letters. The analysis considered any work available in WoS between 1985 and 2019 to capture as many possible combinations of terms relate to IM in SMEs. This search finds 3117 academic papers, that have become 3055 academic papers by only considering articles, reviews, and letters available in WoS.

Step 2. Additionally, the search was defined by management, business, economics, industrial engineering, and operation re- 
search management science. After applying this filter, a sample of 1,772 were the total number of documents obtained. Until 2019, IM in SME had received 25,260 citations from other documents available in the WoS database. This results in an average number of citations per article of 15.04 , and the $\mathrm{h}$ index was 72 . Of the 1,772 documents, 72 have received 72 citations or more, in addition to articles in which they are cited. The search began on June 6, 2021.

Step 3. Moreover, this study included bibliometric indicator citations by year, citations by paper, thresholds by appointment, and the articles they cited. Another indicator is the h-index (Hirsch, 2005) proposed and defined by the physicist Hirsch to measure a researcher's productivity to take into account his publications and citations obtained. The h-index combines articles with citations indicating " $x$ " number of studies that have received " $y$ " or more citations. In addition, this study considers a ranking of universities in the Academic Ranking of World Universities (ARWU) and the Quacquarelli Symonds University Ranking (QS). These bibliometric indicators allow the display of the information and facilitate the understanding of the topic.

Step 4 . Finally, the study graphically maps the bibliographic material using VOSviewer. The VOSviewer has been used in several studies (Caputo et al., 2018; Martínez-López et al., 2020; Sarkodie \& Strezov, 2019; Shah et al., 2020) to collect data employed to conduct co-citation, bibliographic coupling, and co-occurrence of author keywords in a descriptive analysis.

\section{RESULTS}

This section presents the results of this bibliometric contribution to IM in SMEs from 1985 to 2019 in the WoS database. It provides tables and figures, classified by the most cited papers, leading journals, and the most productive authors, institutions, and countries.

\subsection{General perspective}

According to the results obtained, the subject of the IM in SMEs has been studied over the years. As a result, it shows a growing evolution, from 1 article in 1985 to 254 in 2019. In addition, many of the publications are concentrated in the last five years; this evolution is observed through the information provided in Figure 1.

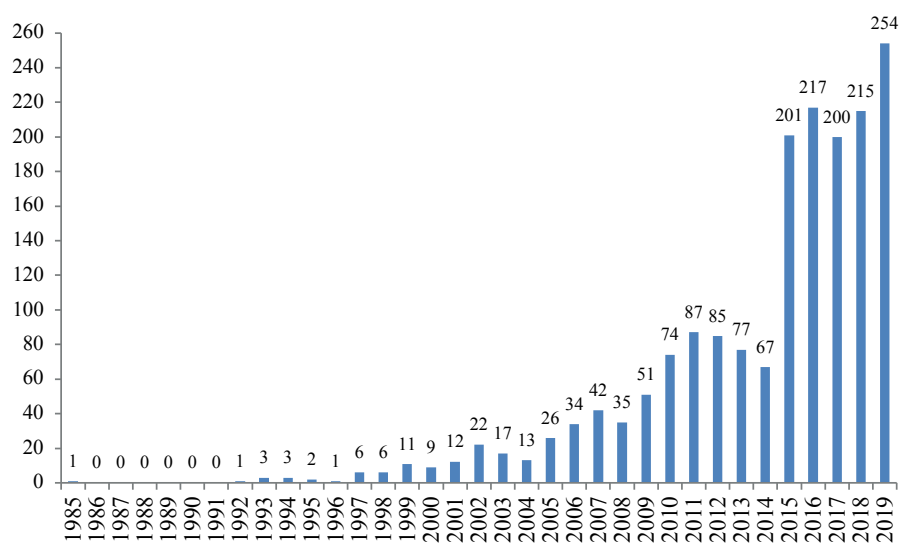

Figure 1

The annual number of papers published in IM in SME

Source: Own elaboration.
Table 1

Annual citation structure of IM in SME

\begin{tabular}{|c|c|c|c|c|c|c|c|c|c|}
\hline \multirow{2}{*}{ Year } & \multirow{2}{*}{ TP } & \multirow{2}{*}{ TC } & \multicolumn{7}{|c|}{ Thresholds } \\
\hline & & & $>200$ & $>100$ & $>\mathbf{5 0}$ & $>20$ & $>10$ & $>5$ & $>1$ \\
\hline 1982 & 0 & 0 & 0 & 0 & 0 & 0 & 0 & 0 & 0 \\
\hline 1983 & 0 & 0 & 0 & 0 & 0 & 0 & 0 & 0 & 0 \\
\hline 1984 & 0 & 0 & 0 & 0 & 0 & 0 & 0 & 0 & 0 \\
\hline 1985 & 1 & 0 & 0 & 0 & 0 & 0 & 0 & 0 & 0 \\
\hline 1986 & 0 & 0 & 0 & 0 & 0 & 0 & 0 & 0 & 0 \\
\hline 1987 & 0 & 0 & 0 & 0 & 0 & 0 & 0 & 0 & 0 \\
\hline 1988 & 0 & 0 & 0 & 0 & 0 & 0 & 0 & 0 & 0 \\
\hline 1989 & 0 & 0 & 0 & 0 & 0 & 0 & 0 & 0 & 0 \\
\hline 1990 & 0 & 0 & 0 & 0 & 0 & 0 & 0 & 0 & 0 \\
\hline 1991 & 0 & 0 & 0 & 0 & 0 & 0 & 0 & 0 & 0 \\
\hline 1992 & 1 & 15 & 0 & 0 & 0 & 0 & 1 & 0 & 0 \\
\hline 1993 & 3 & 57 & 0 & 0 & 0 & 1 & 0 & 1 & 1 \\
\hline 1994 & 3 & 64 & 0 & 0 & 1 & 0 & 0 & 0 & 0 \\
\hline 1995 & 2 & 23 & 0 & 0 & 0 & 1 & 0 & 0 & 1 \\
\hline 1996 & 1 & 4 & 0 & 0 & 0 & 0 & 0 & 0 & 1 \\
\hline 1997 & 6 & 65 & 0 & 0 & 0 & 1 & 2 & 2 & 1 \\
\hline 1998 & 6 & 122 & 0 & 0 & 1 & 1 & 1 & 2 & 0 \\
\hline 1999 & 11 & 758 & 1 & 3 & 1 & 1 & 2 & 1 & 2 \\
\hline 2000 & 9 & 375 & 0 & 0 & 5 & 1 & 0 & 1 & 1 \\
\hline 2001 & 12 & 596 & 1 & 1 & 1 & 4 & 0 & 2 & 2 \\
\hline 2002 & 22 & 1011 & 1 & 1 & 3 & 9 & 5 & 1 & 2 \\
\hline 2003 & 17 & 593 & 0 & 2 & 2 & 5 & 3 & 2 & 2 \\
\hline 2004 & 13 & 716 & 1 & 1 & 3 & 3 & 2 & 0 & 2 \\
\hline 2005 & 26 & 1913 & 2 & 3 & 4 & 8 & 3 & 2 & 4 \\
\hline 2006 & 34 & 1748 & 1 & 3 & 11 & 8 & 5 & 3 & 1 \\
\hline 2007 & 42 & 1525 & 2 & 1 & 3 & 7 & 8 & 5 & 7 \\
\hline 2008 & 35 & 739 & 0 & 0 & 6 & 6 & 6 & 4 & 7 \\
\hline 2009 & 51 & 2101 & 2 & 5 & 7 & 10 & 4 & 6 & $S$ \\
\hline 2010 & 74 & 1879 & 1 & 2 & 9 & 16 & 10 & 13 & 13 \\
\hline 2011 & 87 & 1629 & 0 & 2 & 7 & 15 & 9 & 12 & 33 \\
\hline 2012 & 85 & 1688 & 0 & 4 & 7 & 13 & 21 & 7 & 14 \\
\hline 2013 & 77 & 1110 & 0 & 1 & 3 & 15 & 17 & 13 & 18 \\
\hline 2014 & 67 & 913 & 0 & 0 & 3 & 11 & 19 & 10 & 13 \\
\hline 2015 & 201 & 1920 & 0 & 0 & 3 & 28 & 33 & 40 & 61 \\
\hline 2016 & 217 & 1561 & 0 & 0 & 2 & 16 & 39 & 46 & 63 \\
\hline 2017 & 200 & 1123 & 0 & 0 & 2 & 12 & 20 & 37 & 84 \\
\hline 2018 & 215 & 645 & 0 & 0 & 0 & 3 & 12 & 27 & 111 \\
\hline 2019 & 254 & 367 & 0 & 0 & 0 & 1 & 5 & 17 & 95 \\
\hline Total & 1772 & 25260 & 12 & 29 & 84 & 196 & 227 & 254 & 548 \\
\hline & $100 \%$ & & 0.67 & 1.63 & 4.7 & 11.06 & 12.81 & 14.33 & 30.92 \\
\hline
\end{tabular}

Note: Abbreviations: $\mathrm{TP}$ and $\mathrm{TC}=$ Total papers and citations; the thresholds $\geq 200, \geq 100, \geq 50, \geq 20, \geq 10, \geq 5, \geq 1$ = number of papers with equal or more than $200,100,50,20,10,5$ and 1 citations respectively.

Source: Own elaboration.

Table 1 presents the growth in the number of citations over time. Of particular note, the study is increasing with a total of 1,772 productions and 25,260 citations. For example, the topic of IM in SMEs was studied mainly in 2016 and 2019 according to the number of publications. Still, the largest number of citations was from 2009, with 2,101 and 55 publications. 
Table 2

The 30 most cited papers in IM in SME between 1985 and 2019

\begin{tabular}{|c|c|c|c|c|c|}
\hline $\mathbf{R}$ & TC & Title & Author/s & $\mathbf{Y}$ & $\mathrm{C} / \mathrm{Y}$ \\
\hline 1 & 499 & Internationalization and the performance of born-global SMEs: the mediating role of social networks & Zhou et al. & $(2007)$ & 42 \\
\hline 2 & 486 & Entrepreneurship, innovation and economic growth: Evidence from GEM data & Wong et al. & $(2005)$ & 35 \\
\hline 3 & 413 & Critical success factors for implementing knowledge management in small and medium enterprises & Yew Wong & $(2005)$ & 30 \\
\hline 4 & 355 & $\begin{array}{l}\text { The competitiveness of small and medium enterprises - A conceptualization with focus on } \\
\text { entrepreneurial competencies }\end{array}$ & Man et al. & $(2002)$ & 21 \\
\hline 5 & 280 & Small and medium enterprises across the globe & Ayyagari et al. & $(2007)$ & 23 \\
\hline 6 & 279 & $\begin{array}{l}\text { Innovation practice and its performance implications in small and medium enterprises (SMEs) } \\
\text { in the manufacturing sector: a resource-based view }\end{array}$ & Terziovski & $(2010)$ & 31 \\
\hline 7 & 235 & SMEs and CSR theory: Evidence and implications from an Italian perspective & Perrini & $(2006)$ & 18 \\
\hline 8 & 215 & Bank competition and access to finance: International evidence & Beck et al. & $(2004)$ & 14 \\
\hline 9 & 214 & $\begin{array}{l}\text { The export orientation and export performance of high-technology SMEs in emerging markets: } \\
\text { The effects of knowledge transfer by returnee entrepreneurs }\end{array}$ & Filatotchev et al. & $(2009)$ & 21 \\
\hline 10 & 208 & $\begin{array}{l}\text { Selecting management systems for sustainable development in SMEs: A novel hybrid model } \\
\text { based on DEMATEL, ANP, and ZOGP }\end{array}$ & Tsai \& Chai. & $(2009)$ & 21 \\
\hline 11 & 204 & Manufacturing strategy - Literature review and some issues & $\begin{array}{l}\text { Dangayach \& } \\
\text { Deshmukh }\end{array}$ & $(2001)$ & 11 \\
\hline 12 & 201 & $\begin{array}{l}\text { Small firms, social capital and the enhancement of business performance through innovation } \\
\text { programmes }\end{array}$ & Cooke \& Wills & $(1999)$ & 10 \\
\hline 13 & 192 & $\begin{array}{l}\text { Convergence Versus Divergence of CSR in Developing Countries: An Embedded Multi-Layered } \\
\text { Institutional Lens }\end{array}$ & Jamali \& Neville & $(2011)$ & 24 \\
\hline 14 & 192 & Innovation and internationalization through exports & Cassiman et al. & $(2011)$ & 24 \\
\hline 15 & 189 & $\begin{array}{l}\text { Intellectual capital and new product development performance: The mediating role of } \\
\text { organizational learning capability }\end{array}$ & Hsu \& Fang & $(2009)$ & 19 \\
\hline 16 & 185 & Knowledge codification and the geography of innovation: the case of Brescia mechanical cluster & Lissoni, F & $(2001)$ & 10 \\
\hline 17 & 182 & SMEs, growth, and poverty: Cross-country evidence & Beck et al. & $(2005)$ & 13 \\
\hline 18 & 172 & The antecedents of SME innovativeness in an emerging transition economy & Radas \& Bozic & $(2009)$ & 17 \\
\hline 19 & 167 & $\begin{array}{l}\text { The competitive advantage of early and rapidly internationalizing SMEs in the biotechnology } \\
\text { industry: A knowledge-based view }\end{array}$ & $\begin{array}{l}\text { Gassmann \& } \\
\text { Keupp. }\end{array}$ & $(2007)$ & 14 \\
\hline 20 & 165 & Factors impacting the adoption of the Internet among SMEs & Dholakia et al. & $(2004)$ & 11 \\
\hline 21 & 157 & The Role of Networks in Small and Medium-Sized Enterprise Innovation and Firm Performance & Gronum et al. & $(2012)$ & 22 \\
\hline 22 & 156 & Peculiar Strengths and Relational Attributes of SMEs in the Context of CSR & Jamali et al. & $(2009)$ & 16 \\
\hline 23 & 155 & Managing 'green' product innovation in small firms & Noci et al. & $(1999)$ & 8 \\
\hline 24 & 153 & Strategic orientation, management characteristics, and performance: A study of Spanish SMEs & $\begin{array}{l}\text { Aragon-Sanchez } \\
\text { et al. }\end{array}$ & $(2005)$ & 11 \\
\hline 25 & 151 & $\begin{array}{l}\text { Information internalization and hurdle rates in small and medium enterprise } \\
\text { internationalization }\end{array}$ & Liesch \& Knight & $(1999)$ & 8 \\
\hline 26 & 145 & International business competence and the contemporary firm & Knight \& Kim & $(2009)$ & 15 \\
\hline 27 & 138 & Innovation systems and 'inertia' in R\&D location: Norwegian firms and the role of systemic lock-in & Narula & $(2002)$ & 8 \\
\hline 28 & 135 & Bank involvement with SMEs: Beyond relationship lending & De la Torre et al. & $(2010)$ & 15 \\
\hline 29 & 133 & $\begin{array}{l}\text { Capabilities, Proactive CSR and Financial Performance in SMEs: Empirical Evidence from an } \\
\text { Australian Manufacturing Industry Sector }\end{array}$ & Torugsa et al. & (2012) & 19 \\
\hline 30 & 129 & $\begin{array}{l}\text { Firm survival through a crisis The influence of market orientation, marketing innovation and } \\
\text { business strategy }\end{array}$ & Naidoo & (2010) & 14 \\
\hline
\end{tabular}

Note: Abbreviations: $\mathrm{R}=$ Rank; $\mathrm{TC}=$ Total citations; $\mathrm{C} / \mathrm{Y}=$ Citations per year.

Source: Own elaboration. 
Table 2 presents the thirty most cited papers of the journal at all times. Keep in mind that for this study, 1985 to 2019 is considered to be a period. Therefore, in this table, the five most cited papers were published in 2002, 2005 and 2007.

Internationalization and the performance of born-global SMEs: The mediating role of social networks is the most cited article with 499 citations, written by Zhou et al. (2007), and is ranked first. This article studies the purported relationship between internationalization and firm performance in the context of born global small and medium enterprises (SMEs) and argues that home-based social networks play a mediating role in the relationship between inward and outward internationalization and firm performance. This paper shows a social network explanation for the purported relationship between internationalization and firm performance in the context of born-global small and medium enterprises (SMEs). Home-based social networks play a mediating role in the relationship between inward and outward internationalization in the firm performance. They used survey data from SMEs in the largest emerging economy of China, they found some support for this mediating role of social networks in the form of guanxi. The results show that international business managers should consider social networks as an efficient means of helping internationally oriented SMEs to go international more rapidly and profitably (Zhou et al., 2007).

Following is the article Entrepreneurship, innovation, and economic growth: Evidence from GEM data with 486 citations and written by Wong et al. (2005). This paper focuses on exploring the impact of entrepreneurship in conjunction with innovation on macro-level economic growth.

Ranked third is the article Critical success factors for implementing knowledge management in small and medium enterprises with 413 citations and is written by Yew Wong (2005). In this article, the author compares, and reviews critical success factors proposed by various authors in the literature for implementing knowledge management in small and medium enterprises (SMEs).

Ranked fourth is the article The competitiveness of small and medium enterprises - A conceptualization focusing on entrepreneurial competencies with a total of 355 citations and written by Man et al. (2002). In this article, the authors develop a conceptual model to link the characteristics of SMEs' owner-managers and their firms' performance.

Finally, the article Small and medium enterprises across the globe are ranked fifth with a total of 280 citations and are written by Ayyagari et al. (2007). This article analyzes the relationship between the relative size of the SME sector and the business environment in 76 countries.

The paper describes a new and unique cross-country database that presents consistent and comparable information on the contribution of the SME sector to total employment in manufacturing and GDP across different countries and relates the importance of SMEs and the informal economy to indicators of different dimensions of the business environment.

\subsection{Leading authors, institutions and countries}

This section will analyse the authors, institutions, and countries that have the most publications about IM in SMEs. First, the most influential authors in the development of this research field will be analyzed. Note that in the case of a tie, the ranking is according to the number of citations.

Table 3 highlights the most important researchers in IM in SMEs and lists thirty authors. Sohn SY is the most productive leader in this classification, with 12 articles, 233 citations and an h-index of 9, followed by Ahmad NH with 11 articles, 21 citations and an h-index of 3. Gunasekaran ranks third, with a total of 9 publications and a considerable number of 268 citations. Gunasekaran stands out for the author with the highest h-index of 57 among the 30 most productive authors.

Finally, Demirguc-Kunt stands out for being the author with the most citations, with a total of 754 citations and five publications. Although this author's level of productivity is not similar to that of leaders, his influence is evident from the total number of citations received.

Next, in Table 4, we analyze the most productive institutions to determine which universities produce the most documents and identify the universities that publish the most science in IM in SMEs.

The World Bank located in the United States is the most productive institution, with 18 papers and 1,288 citations, the highest number in this top 30. The Indian Institute of Technology System IIT System located in India ranked second, with 18 papers but fewer citations (390).

Likewise, in this top 30, the countries with the largest institutions are Malaysia, Spain, Italy, and the United States.

Another aspect to consider is that universities are highlighted by their h-index. For example, the State University System of Florida, located in the USA, has an h-index of 13 and 412 citations by paper.

Countries make considerable efforts to promote scientific development. This development places them at the forefront and enables them to attain a leading position in the research field. Table 5 highlights the most important countries that have contributed to the development of the IM in SMEs. The USA is the most influential country on the topic, the most productive with 169 papers, the most cited country with 5,369 total citations, and highlights with the h-index 38 . England is ranked second, with 12 papers of difference and 3,701 citations and an h-index of 36 . Italy, which has 142 publications and 2,820 of the total citations of the total productivity, ranks third; its h-index is 30 . India is another country with important productivity, with 132 publications, an h-index of 17, and 1,215 citations. From this perspective, Spain and China obtain remarkable results, ranking fifth and sixth, respectively. 
Table 3

Top 30 most productive and influential authors in IM in SMEs

\begin{tabular}{|c|c|c|c|c|c|c|c|c|c|c|}
\hline \multirow{2}{*}{$\mathbf{R}$} & \multirow{2}{*}{ Author } & \multirow{2}{*}{ University } & \multirow{2}{*}{ Country } & \multirow{2}{*}{ TP } & \multirow{2}{*}{ TC } & \multirow{2}{*}{$\mathbf{H}$} & \multirow{2}{*}{$\mathrm{C} / \mathrm{P}$} & \multicolumn{3}{|c|}{ Thresholds } \\
\hline & & & & & & & & $\geq 200$ & $\geq 100$ & $\geq 50$ \\
\hline 1 & Sohn SY & Yonsei University & South Korea & 12 & 233 & 9 & 25.89 & 0 & 0 & 1 \\
\hline 2 & Ahmad NHs & Universiti Sains Malaysia & Malaysia & 11 & 21 & 3 & 7 & 0 & 0 & 0 \\
\hline 3 & Gunasekaran & $\begin{array}{l}\text { California State University } \\
\text { Bakersfield }\end{array}$ & USA & 9 & 268 & 57 & 4.70 & 0 & 0 & 3 \\
\hline 4 & Ramayah T & Universiti Sains Malaysia & Malaysia & 9 & 16 & 26 & 0.62 & 0 & 0 & 0 \\
\hline 5 & Halim Ha & Universiti Sains Malaysia & Malaysia & 8 & 7 & 7 & 1 & 0 & 0 & 0 \\
\hline 6 & Garengo P & University of Padua & Italy & 7 & 191 & 15 & 12.73 & 0 & 0 & 1 \\
\hline 7 & Depablos Po & University of Oviedo & Spain & 7 & 14 & 21 & 0.67 & 0 & 0 & 0 \\
\hline 8 & Belas J & Tomas Bata University Zlin & Czech Republic & 6 & 120 & 15 & 8 & 0 & 0 & 0 \\
\hline 9 & Lee $\mathrm{H}$ & Tokyo University of Technology & Japan & 6 & 147 & 1 & 147 & 0 & 0 & 1 \\
\hline 10 & Esposito E & University of Naples Federico II & Italy & 6 & 122 & 18 & 6.78 & 0 & 0 & 0 \\
\hline 11 & Paoluccie E & Polytechnic University of Turin & Italy & 6 & 70 & 8 & 8.75 & 0 & 0 & 1 \\
\hline 12 & Rahman Sa & $\begin{array}{l}\text { National University of Sciences \& } \\
\text { Technology }\end{array}$ & Pakistan & 6 & 11 & 8 & 1.38 & 0 & 0 & 0 \\
\hline 13 & Demirguc-Kunt A & The World Bank & USA & 5 & 754 & 49 & 15.39 & 2 & 1 & 1 \\
\hline 14 & Cerchioner R & Parthenope University Naples & Italy & 5 & 117 & 14 & 8.36 & 0 & 0 & 0 \\
\hline 15 & Kumar V & Roever Coll Engn \& Technol & India & 5 & 51 & 1 & 51 & 0 & 0 & 0 \\
\hline 16 & Neirotti P & Polytechnic University of Turin & Italy & 5 & 30 & 12 & 2.50 & 0 & 0 & 0 \\
\hline 17 & Rahman A & Tomas Bata University Zlin & Czech Republic & 5 & 43 & 4 & 10.75 & 0 & 0 & 0 \\
\hline 18 & Rasiah R & Universiti Malaya & Malaysia & 5 & 27 & 17 & 1.59 & 0 & 0 & 0 \\
\hline 19 & Lesakoval L & Matej Bel University & Slovakia & 5 & 18 & 5 & 3.60 & 0 & 0 & 0 \\
\hline 20 & Kharub M & CVR Coll Engn & India & 5 & 17 & 13 & 1.31 & 0 & 0 & 0 \\
\hline 21 & Beck T & University of London & England & 4 & 704 & 41 & 17.17 & 2 & 1 & 0 \\
\hline 22 & Dangayach GS & $\begin{array}{l}\text { Malaviya National Institute of } \\
\text { Technology Jaipur }\end{array}$ & India & 4 & 246 & 14 & 17.57 & 1 & 0 & 0 \\
\hline 23 & Gupta H & Shri Mata Vaishno Devi University & India & 4 & 104 & 2 & 52 & 0 & 0 & 1 \\
\hline 24 & Barua Mk & Indian Institute of Technology & India & 4 & 96 & 14 & 6.86 & 0 & 0 & 1 \\
\hline 25 & Centobelli P & University of Naples Federico II & Italy & 4 & 85 & 11 & 7.73 & 0 & 0 & 0 \\
\hline 26 & Cegarra-Navarro JG & Universidad Politecnica of Cartagena & Spain & 4 & 71 & 20 & 3.55 & 0 & 0 & 0 \\
\hline 27 & Afrifa Ga & University of Kent & England & 4 & 32 & 5 & 6.40 & 0 & 0 & 0 \\
\hline 28 & Fan L & Wuhan University of Technology & China & 4 & 23 & 4 & 5.75 & 0 & 0 & 0 \\
\hline 29 & $\mathrm{Bi} \mathrm{Gb}$ & $\begin{array}{l}\text { University of Science \& Technology } \\
\text { of China }\end{array}$ & China & 4 & 11 & 3 & 3.67 & 0 & 0 & 0 \\
\hline 30 & Aliz Z & $\begin{array}{l}\text { University of Science \& Technology } \\
\text { of China }\end{array}$ & China & 4 & 10 & 2 & 5 & 0 & 0 & 0 \\
\hline
\end{tabular}

Note: Abbreviations available in Tables 1 and 3 except: $\mathrm{C} / \mathrm{P}=$ Cites per paper; $\mathrm{H}=\mathrm{h}$-index.

Source: Own elaboration. 
Table 4

Top 30 most productive and influential institutions in the IM in SMEs

\begin{tabular}{|c|c|c|c|c|c|c|c|c|c|c|c|}
\hline \multirow{2}{*}{$\mathbf{R}$} & \multirow{2}{*}{ Institution } & \multirow{2}{*}{ Country } & \multirow{2}{*}{ TP } & \multirow{2}{*}{ TC } & \multirow{2}{*}{$\mathrm{C} / \mathrm{P}$} & \multirow{2}{*}{$\mathbf{H}$} & \multicolumn{3}{|c|}{ Thresholds } & \multirow{2}{*}{ ARWU } & \multirow{2}{*}{ QS } \\
\hline & & & & & & & $\geq \mathbf{2 0 0}$ & $\geq 100$ & $\geq 50$ & & \\
\hline 1 & The World Bank & USA & 18 & 1288 & 71.56 & 12 & 2 & 3 & 3 & & \\
\hline 2 & $\begin{array}{l}\text { Indian Institute of Technology } \\
\text { System IIT System }\end{array}$ & India & 18 & 390 & 21.67 & 7 & 1 & 0 & 1 & $501-600$ & 172 \\
\hline 3 & Universiti Sains Malaysia & Malaysia & 17 & 76 & 4.47 & 6 & 0 & 0 & 0 & $501-600$ & 207 \\
\hline 4 & Universiti Malaya & Malaysia & 16 & 164 & 10.25 & 7 & 0 & 0 & 1 & $301-400$ & 87 \\
\hline 5 & University of Padua & Italy & 14 & 311 & 22.21 & 8 & 0 & 0 & 2 & $201-300$ & 249 \\
\hline 6 & Polytechnic University of Milan & Italy & 13 & 419 & 32.23 & 9 & 0 & 1 & 1 & $201-300$ & 156 \\
\hline 7 & Yonsei University & South Korea & 13 & 254 & 19.54 & 9 & 0 & 0 & 1 & $201-300$ & 107 \\
\hline 8 & Polytechnic University of Turin & Italy & 13 & 126 & 9.69 & 6 & 0 & 0 & 1 & $501-600$ & $571-580$ \\
\hline 9 & University of Valencia & Spain & 12 & 154 & 12.83 & 5 & 0 & 0 & 1 & $201-300$ & $561-570$ \\
\hline 10 & $\begin{array}{l}\text { Bucharest University of Economic } \\
\text { Studies }\end{array}$ & Romania & 12 & 79 & 6.58 & 5 & 0 & 0 & 0 & $901-1000$ & $801-1000$ \\
\hline 11 & Universiti Teknologi Malaysia & Malaysia & 11 & 572 & 52 & 6 & 1 & 0 & 1 & $501-600$ & 228 \\
\hline 12 & University of Zagreb & Croatia & 11 & 256 & 23.27 & 5 & 0 & 1 & 0 & $401-500$ & $801-1000$ \\
\hline 13 & University System of Georgia & USA & 11 & 136 & 12.36 & 5 & 0 & 0 & 1 & $501-600$ & 431 \\
\hline 14 & $\begin{array}{l}\text { Universidad Politecnica of } \\
\text { Cartagena }\end{array}$ & Spain & 11 & 90 & 8.18 & 5 & 0 & 0 & 0 & & \\
\hline 15 & State University System of Florida & USA & 10 & 412 & 41.20 & 13 & 0 & 2 & 1 & $201-300$ & 472 \\
\hline 16 & University of Murcia & Spain & 10 & 370 & 37 & 6 & 0 & 2 & 1 & $701-800$ & $801-1000$ \\
\hline 17 & Tomas Bata University Zlin & Czech Republic & 10 & 159 & 15.90 & 7 & 0 & 0 & 0 & & \\
\hline 18 & University of Nottingham & United Kingdom & 9 & 328 & 36.44 & 6 & 1 & 0 & 1 & $101-150$ & 82 \\
\hline 19 & Massey University & New Zealand & 9 & 204 & 22.67 & 6 & 0 & 0 & 1 & $601-700$ & 332 \\
\hline 20 & Universidade do Minho & Portugal & 9 & 162 & 18 & 5 & 0 & 0 & 0 & $401-500$ & $651-700$ \\
\hline 21 & Brunel University & United Kingdom & 9 & 94 & 10.44 & 6 & 0 & 0 & 0 & $501-600$ & 332 \\
\hline 22 & University of Ljubljana & Slovenia & 9 & 89 & 9.89 & 6 & 0 & 0 & 0 & $501-600$ & 651.7 \\
\hline 23 & Complutense University of Madrid & Spain & 9 & 74 & 8.22 & 5 & 0 & 0 & 0 & $201-300$ & 206 \\
\hline 24 & University of Zulia & Venezuela & 9 & 3 & 0.33 & 1 & 0 & 0 & 0 & & \\
\hline 25 & Bocconi University & Italy & 8 & 495 & 61.88 & 4 & 1 & 1 & 1 & & \\
\hline 26 & Deakin University & Australia & 8 & 191 & 23.88 & 5 & 0 & 1 & 0 & 201-300 & 309 \\
\hline 27 & Multimedia University & Malaysia & 8 & 173 & 21.63 & 4 & 0 & 1 & 0 & & $801-1000$ \\
\hline 28 & California State University System & USA & 8 & 130 & 16.25 & 4 & 0 & 0 & 1 & & \\
\hline 29 & Islamic Azad University & Iran & 8 & 62 & 7.75 & 4 & 0 & 0 & 0 & & \\
\hline 30 & $\begin{array}{l}\text { Hse University National Research } \\
\text { University Higher Scool of } \\
\text { Economics }\end{array}$ & Russia & 8 & 46 & 5.75 & 3 & 0 & 0 & 0 & $901-1000$ & 343 \\
\hline
\end{tabular}

Note: Abbreviations are available in the previous tables except: ARWU and QS = Ranking in the general ARWU and QS university rankings. Source: Own elaboration. 
Table 5

Top 30 most productive and influential countries in the IM in SMEs

\begin{tabular}{|c|c|c|c|c|c|c|c|c|c|c|}
\hline \multirow{2}{*}{$\mathbf{R}$} & \multirow{2}{*}{ Country } & \multirow{2}{*}{ TP } & \multirow{2}{*}{ TC } & \multirow{2}{*}{$\mathbf{H}$} & \multirow{2}{*}{$\mathrm{C} / \mathrm{P}$} & \multicolumn{3}{|c|}{ Thresholds } & \multirow{2}{*}{$\mathbf{P} / \mathbf{P o}$} & \multirow{2}{*}{$\mathrm{C} / \mathrm{Po}$} \\
\hline & & & & & & $\geq 200$ & $\geq 100$ & $\geq \mathbf{5 0}$ & & \\
\hline 1 & USA & 169 & 5369 & 38 & 31.77 & 3 & 11 & 18 & 0.51 & 16.32 \\
\hline 2 & England & 157 & 3701 & 36 & 23.57 & 1 & 3 & 22 & 2.36 & 55.53 \\
\hline 3 & Italy & 142 & 2820 & 30 & 19.86 & 1 & 2 & 8 & 2.35 & 46.57 \\
\hline 4 & India & 132 & 1215 & 17 & 9.20 & 1 & 0 & 4 & 0.10 & 0.89 \\
\hline 5 & Spain & 120 & 2052 & 24 & 17.10 & 1 & 2 & 8 & 2.57 & 43.90 \\
\hline 6 & China & 93 & 2086 & 21 & 22.43 & 2 & 0 & 7 & 0.06 & 1.45 \\
\hline 7 & Malaysia & 86 & 1356 & 17 & 15.77 & 1 & 1 & 5 & 2.69 & 42.44 \\
\hline 8 & Australia & 85 & 2567 & 24 & 30.20 & 1 & 4 & 10 & 3.37 & 101.87 \\
\hline 9 & South Korea & 62 & 1014 & 18 & 16.35 & 0 & 1 & 4 & 1.21 & 19.79 \\
\hline 10 & France & 53 & 809 & 15 & 15.26 & 0 & 1 & 5 & 0.81 & 12.42 \\
\hline 11 & Taiwan & 53 & 1421 & 22 & 26.81 & 4 & 0 & 3 & 2.23 & 59.78 \\
\hline 12 & Indonesia & 49 & 237 & 8 & 4.84 & 0 & 0 & 1 & 0.18 & 0.88 \\
\hline 13 & Poland & 48 & 235 & 8 & 4.90 & 0 & 0 & 0 & 1.27 & 6.20 \\
\hline 14 & Germany & 47 & 443 & 12 & 9.43 & 0 & 0 & 1 & 0.56 & 5.30 \\
\hline 15 & South Africa & 47 & 186 & 8 & 3.96 & 0 & 0 & 0 & 0.80 & 3.18 \\
\hline 16 & Brazil & 45 & 271 & 8 & 6.02 & 0 & 0 & 2 & 0.21 & 1.28 \\
\hline 17 & Portugal & 44 & 555 & 14 & 12.61 & 0 & 0 & 0 & 4.30 & 54.25 \\
\hline 18 & Japan & 43 & 675 & 14 & 15.70 & 0 & 0 & 5 & 0.34 & 5.32 \\
\hline 19 & Mexico & 41 & 165 & 5 & 4.02 & 0 & 0 & 1 & 0.32 & 1.29 \\
\hline 20 & Canada & 40 & 856 & 17 & 21.40 & 0 & 1 & 4 & 0.61 & 13.14 \\
\hline 21 & Slovakia & 37 & 299 & 10 & 8.08 & 0 & 0 & 0 & 6.78 & 54.76 \\
\hline 22 & Czech Republic & 29 & 393 & 10 & 13.55 & 0 & 0 & 1 & 2.71 & 36.73 \\
\hline 23 & Netherlands & 26 & 855 & 14 & 32.88 & 2 & 0 & 1 & 1.52 & 50 \\
\hline 24 & Thailand & 25 & 155 & 7 & 6.20 & 0 & 0 & 0 & 0.36 & 2.23 \\
\hline 25 & New Zealand & 24 & 501 & 10 & 20.88 & 0 & 0 & 4 & 5.02 & 104.81 \\
\hline 26 & Romania & 24 & 162 & 7 & 6.75 & 0 & 0 & 0 & 1.24 & 8.36 \\
\hline 27 & Russia & 23 & 104 & 5 & 4.52 & 0 & 0 & 0 & 0.16 & 0.71 \\
\hline 28 & Colombia & 22 & 67 & 5 & 3.05 & 0 & 0 & 0 & 0.44 & 1.33 \\
\hline 29 & Pakistan & 22 & 119 & 7 & 5.41 & 0 & 0 & 0 & 0.10 & 0.55 \\
\hline 30 & Iran & 21 & 214 & 6 & 10.19 & 0 & 0 & 1 & 0.25 & 2.58 \\
\hline
\end{tabular}

Note: Abbreviations available in previous tables except: $\mathrm{P} / \mathrm{Po}$ and $\mathrm{C} / \mathrm{Po}=$ Papers and cites per million inhabitants.

Source: Own elaboration.

\subsection{Graphical analysis of IM in SMEs with VOSviewer}

In this section, to provide a deeper analysis of the data obtained from the search, we graphically analyze bibliographic material about IM in SMEs using the VOSviewer software (van Eck \& Waltman, 2010).

This program can build and view graphic maps through bibliographic coupling, analysis of citations and cocitations, coauthorship, and co-occurrence of author keywords (Caputo et al., 2018; Shukla et al., 2020).

Recall that bibliographic coupling appears when two documents cite the same third document (Kessler, 1963). Cocitation between two documents occurs when they receive a citation from the same third document. The co-occurrence of author keywords measures the most common keywords and those that appear more frequently in the same papers.

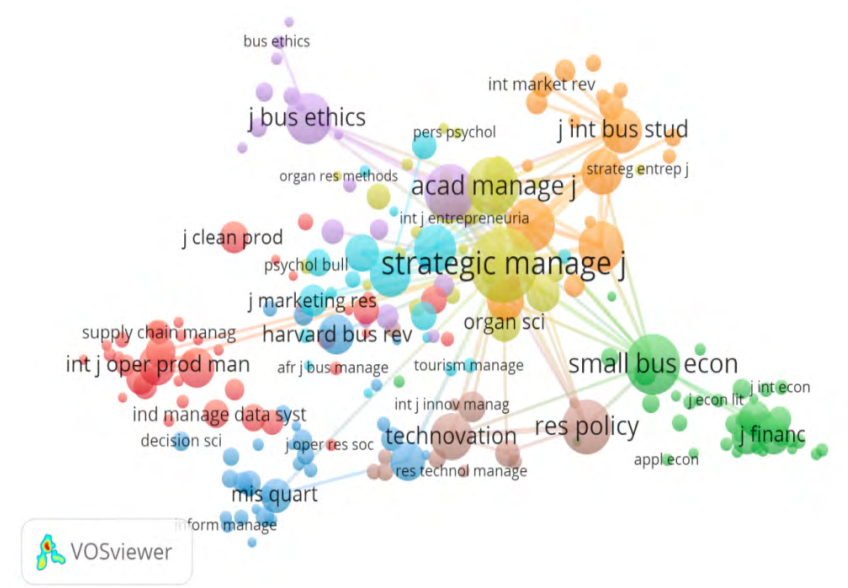

Figure 2

Cocitation of journals cited in IM in SMEs Source: Own elaboration. 
Figure 2 presents the general visualization between 1985 and 2019 with a minimum of fifty cites and the 210 most representative connections. Note that the colours of the journals' circles indicate the cluster to which the journals belong.

Next, the bibliographic coupling of authors that publish IM in SMEs will be analyzed. Figure 3 presents the most productive authors with a minimum of two published documents and the three hundred fifty-six strongest bibliographic coupling links between authors. The advantage of this figure is the graphical mapping of authors that connects or clusters those with similar research profiles, those that cite similar bibliographic material. The results of this figure are under Table 3.



Figure 3

Bibliographic coupling of authors that publish in IM in SMEs Source: Own elaboration.

Next, the bibliographic coupling of institutions will be examined. Figure 4 visualizes the data considering a minimum threshold of two documents and 119 connections. In addition to presenting as many registered documents with a higher h-index, the World Bank has a strong relationship with various institutions.

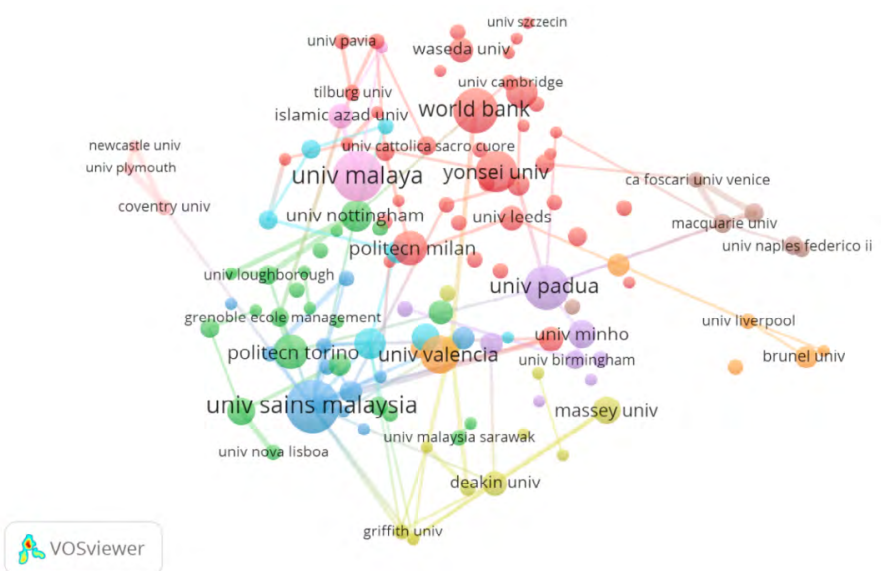

Figure 4

Bibliographic coupling of institutions that publish in IM in SMEs Source: Own elaboration.

To summarize the results at the country level, Figure 5 presents the bibliographic coupling of countries with a threshold of two documents and eighty connections. The results are under Table 5, where the USA is the most productive country, followed by England. The countries in the first positions are related to most other countries. On the other hand, countries with lower weights are related only to countries ranked first in production and data.

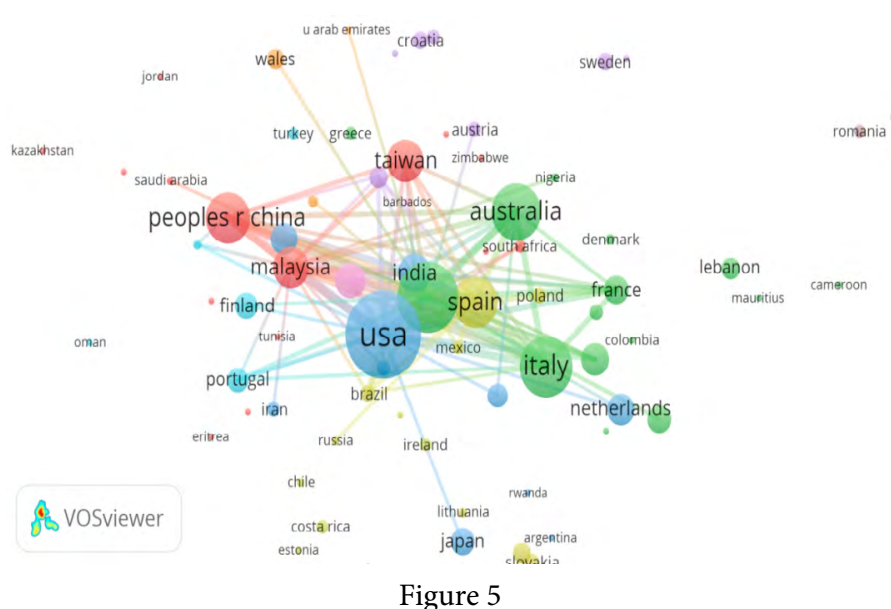

Bibliographic coupling of countries that publish in IM in SMEs Source: Own elaboration.

Figure 6 considers the coincidence of the author's keywords of the period 1985-2019by analyzing the main keywords of the topic IM in SMEs and considering a threshold of twelve occurrences and the forty-five most representative connections. It is noted that the larger node refers to the keywords "small and medium enterprises" as a central theme that has been carried out for the development of the research field and presents 288 Author keyword occurrences and 182 Author keyword co-occurrences links.

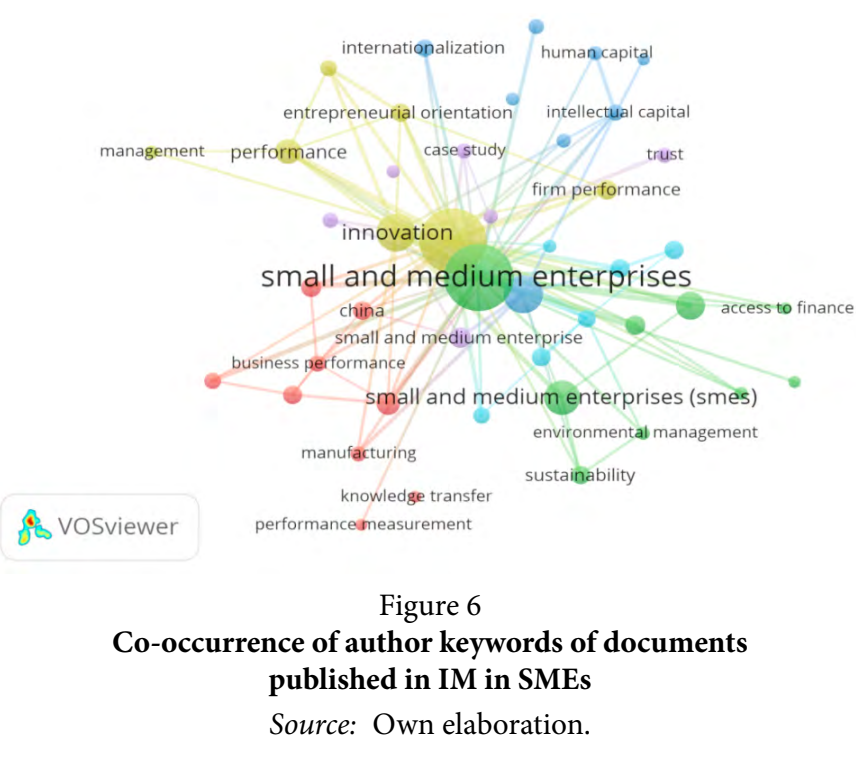

\section{CONCLUSIONS}

This work presents a general overview of the most cited articles, the leading authors, institutions, countries and journals in IM in SMEs between 1985 and 2019. In addition, different anal- 
yses were performed, both at a general level for the described based on the Web of Science database (WoS) in which the sample is 1,772 .

The first IM in SME was identified to have been studied primarily in 2016 and 2019. This finding indicates the recent relevance of IM in SMEs. The highest number of citations over time is shown in 2009, with 2,101 citations and 55 publications. The publications in this research area are growing exponentially, and we have to develop bibliometric tools that allow us to address the IM in SME research that is appearing in science.

Second, the analysis focused on studying a ranking of 30 authors, 30 institutions and 30 countries, leading to greater productivity in the discipline. In this ranking, one can observe an interesting discussion that reveals that the most productive institution also has the most productive country, i.e., those who have a greater quantity of published work. Furthermore, one can observe who the most influential are, i.e., those who have more citations by the scientific community.

Additionally, it is possible to observe that the most productive authors are not necessarily the most influential. Those authors are neither in the most productive institutions nor the most productive countries; only one case, Gunasekaran A, is the third most productive author.

Finally, within the IM in SMEs investigation, the keyword is "small and medium enterprises". This finding indicates the relevance of its evolution.

The results of this paper can be useful for researchers and students who want to deepen the study of IM in SMEs by providing a pathway to building a theoretical framework on the subject and appropriate analysis of new developments in IM in SMEs.

\subsection{Future research}

The study uses Web of Science as the only database; however, in future research, the results may be expanded by using other databases. IM in SMEs research will continue growing, and it is necessary to deepen the analysis of the authors, countries and universities that lead research in this discipline, which are not only the most productive authors but also the most influential.

Another important future research direction is to conduct a more in-depth analysis of these studies by country. This will be important because the realities and characteristics of each country are different, and knowing how IM is being done in different places can improve the success when migrating strategies from other countries or areas.

\section{ACKNOWLEDGMENT}

This research was funded by the Chilean Government through FONDECYT initiation, grant number 11190056. Research supported by Red Sistemas Inteligentes y Expertos Modelos Computacionales Iberoamericanos (SIEMCI), project number 522RT0130 in Programa Iberoamericano de Ciencia y Tecnologia para el Desarrollo (CYTED)

\section{REFERENCES}

Alfaro-García, V.G., Gil-Lafuente, A. M., \& Alfaro Calderón, G. G. (2017). A fuzzy methodology for innovation management measurement. Kybernetes, 46(1), 50-66. https://doi.org/10.1108/K-06-2016-0153

Aragón-Sánchez, A., \& Sánchez-Marín, G. (2005). Strategic orientation, management characteristics, and performance: A study of Spanish SMEs. Journal of Small Business Management, 43(3), 287-308. https://doi.org/10.1111/j.1540-627X.2005.00138.x

Ayyagari, M., Beck, T., \& Demirguc-Kunt, A. (2007). Small and medium enterprises across the globe. Small Business Economics, 29(4), 415434. https://doi.org/10.1007/s11187-006-9002-5

Beck, T., Demirguc-Kunt, A., \& Levine, R. (2005). SMEs, growth, and poverty: Cross-country evidence. Journal of Economic Growth, 10(3), 199-229. https://doi.org/10.1007/s10887-005-3533-5

Beck, T., Demirgüç-Kunt, A., \& Maksimovic, V. (2004). Bank competition and access to finance: International evidence. Journal of Money, Credit and Banking, 627-648.

Bhattacharyya, S. S., \& Verma, S. (2020). The intellectual contours of corporate social responsibility literature: Co-citation analysis study. International Journal of Sociology and Social Policy, 40(11-12), 15511583. https://doi.org/10.1108/IJSSP-12-2019-0263

Bilton, C., \& Cummings, S. (2010). Creative strategy: Reconnecting business and innovation (Vol. 3). John Wiley \& Sons.

Blanco-Mesa, F., Merigó, J. M., \& Gil-Lafuente, A. M. (2017). Fuzzy decision making: A bibliometric-based review. Journal of Intelligent \& Fuzzy Systems, 32(3), 2033-2050.

Bruns, T., \& Stalker, G. (1961). The management of innovation. Tavistock, London, 120-122.

Byington, E. K., Felps, W., \& Baruch, Y. (2019). Mapping the Journal of Vocational Behavior: A 23-year review. Journal of Vocational Behavior, 110, 229-244. https://doi.org/10.1016/j.jvb.2018.07.007

Cancino, C. A., Merigo, J. M., Torres, J. P., \& Diaz, D. (2018). A bibliometric analysis of venture capital research. Journal of Economics, Finance and Administrative Science, 23(45), 182-195. https://doi. org/10.1108/JEFAS-01-2018-0016

Caputo, A., Marzi, G., Pellegrini, M. M., \& Rialti, R. (2018). Conflict management in family businesses: A bibliometric analysis and systematic literature review. International Journal of Conflict Management, 29(4), 519-542. https://doi.org/10.1108/IJCMA-02-2018-0027

Cassiman, B., \& Golovko, E. (2011). Innovation and internationalization through exports. Journal of International Business Studies, 42(1), 56-75. https://doi.org/10.1057/jibs.2010.36

Cooke, P., \& Wills, D. (1999). Small Firms, Social Capital and the Enhancement of Business Performance Through Innovation Programmes. Small Business Economics, 13(3), 219-234. https://doi. org/10.1023/A:1008178808631

Dangayach, G. S., \& Deshmukh, S. G. (2001). Manufacturing strategy Literature review and some issues. International Journal of Operations and Production Management, 21(7), 884-932. https://doi. org/10.1108/01443570110393414

de la Torre, A., Martínez Pería, M. S., \& Schmukler, S. L. (2010). Bank involvement with SMEs: Beyond relationship lending. Journal of Banking and Finance, 34(9), 2280-2293. https://doi.org/10.1016/j. jbankfin.2010.02.014

Dholakia, R. R., \& Kshetri, N. (2004). Factors impacting the adoption of the Internet among SMEs. Small Business Economics, 23(4), 311322. https://doi.org/10.1023/B:SBEJ.0000032036.90353.1f

Donthu, N., Kumar, S., \& Pattnaik, D. (2020). Forty-five years of Journal of Business Research: A bibliometric analysis. Journal of Business Research, 109, 1-14. https://doi.org/10.1016/j.jbusres.2019.10.039

Escorsa, P., \& Valls Pasola, J. (1997). Tecnología e innovación en la empresa: Dirección y gestión. Edicions UPC. 
Eveleens, C. (2010). Innovation management; a literature review of innovation process models and their implications. Science, 800(2010), 900-916.

Filatotchev, I., Liu, X., Buck, T., \& Wright, M. (2009). The export orientation and export performance of high-technology SMEs in emerging markets: The effects of knowledge transfer by returnee entrepreneurs. Journal of International Business Studies, 40(6), 10051021. https://doi.org/10.1057/jibs.2008.105

Gassmann, O., \& Keupp, M. M. (2007). The competitive advantage of early and rapidly internationalising SMEs in the biotechnology industry: A knowledge-based view. Journal of World Business, 42(3), 350-366. https://doi.org/10.1016/j.jwb.2007.04.006

Gronum, S., Verreynne, M.-L., \& Kastelle, T. (2012). The Role of Networks in Small and Medium-Sized Enterprise Innovation and Firm Performance. Journal of Small Business Management, 50(2), 257 282. https://doi.org/10.1111/j.1540-627X.2012.00353.X

Gutiérrez-Salcedo, M., Martínez, M. Á., Moral-Munoz, J. A., Herrera-Viedma, E., \& Cobo, M. J. (2018). Some bibliometric procedures for analyzing and evaluating research fields. Applied Intelligence, 48(5), 1275-1287. https://doi.org/10.1007/s10489-017-1105-y

Herr, H., \& Nettekoven, Z. M. (2018). The role of small and medium-sized enterprises in development: What can be learned from the German experience? Global Labour University Working Paper.

Hervas-Oliver, J.-L., Sempere-Ripoll, F., Boronat-Moll, C., \& Rojas, R. (2015). Technological innovation without R\&D: unfolding the extra gains of management innovations on technological performance. Technology Analysis and Strategic Management, 27(1), 19-38. https://doi.org/10.1080/09537325.2014.944147

Hirsch, J. E. (2005). An index to quantify an individual's scientific research output. Proceedings of the National academy of Sciences, 102(46), 16569-16572.

Hsu, Y.-H., \& Fang, W. (2009). Intellectual capital and new product development performance: The mediating role of organizational learning capability. Technological Forecasting and Social Change, 76(5), 664-677. https://doi.org/10.1016/j.techfore.2008.03.012

Hurley, R. F., \& Hult, G. T. M. (1998). Innovation, market orientation, and organizational learning: An integration and empirical examination. Journal of marketing, 62(3), 42-54.

Igartua, J. I., \& Errasti, A. (2007). La Innovación en una Corporación Industrial: El caso de MCC. 1127-1136.

Jamali, D., \& Neville, B. (2011). Convergence Versus Divergence of CSR in Developing Countries: An Embedded Multi-Layered Institutional Lens. Journal of Business Ethics, 102(4), 599-621. https://doi. org/10.1007/s10551-011-0830-0

Jamali, D., Zanhour, M., \& Keshishian, T. (2009). Peculiar strengths and relational attributes of SMEs in the context of CSR. Journal of Business Ethics, 87(3), 355-377. https://doi.org/10.1007/s10551-0089925-7

Keizer, J. A., Dijkstra, L., \& Halman, J. I. M. (2001). Explaining innovative efforts of SMEs. An exploratory survey among SMEs in the mechani$\mathrm{cal}$ and electrical engineering sector in The Netherlands. Technovation, 22(1), 1-13. https://doi.org/10.1016/S0166-4972(00)00091-2

Kessler, M. M. (1963). Bibliographic coupling between scientific papers. American documentation, 14(1), 10-25.

Keupp, M.M., Palmié, M. and Gassmann, O., 2012. The strategic management of innovation: a systematic review and paths for future research. HYPERLINK "http://www.emeraldinsight.com/ action/showLinks?crossref $=10.1111 \% 2 \mathrm{Fj} .1468-2370.2011 .00321 . x \& \mathrm{i}-$ si=000310542700001" International Journal of Management Reviews, 14(4), 367-390.

Knight, G. A., \& Kim, D. (2009). International business competence and the contemporary firm. Journal of International Business Studies, 40(2), 255-273. https://doi.org/10.1057/palgrave.jibs.8400397
Kokol, P., Saranto, K., \& Blažun Vošner, H. (2018). eHealth and health informatics competences: A systemic analysis of literature production based on bibliometrics. Kybernetes, 47(5), 1018-1030. https:// doi.org/10.1108/K-09-2017-0338

Liesch, P. W., \& Knight, G. A. (1999). Information internalization and hurdle rates in small and medium enterprise internationalization. Journal of International Business Studies, 30(2), 383-394. https://doi. org/10.1057/palgrave.jibs. 8490075

Lissoni, F. (2001). Knowledge codification and the geography of innovation: The case of Brescia mechanical cluster. Research Policy, 30(9), 1479-1500. https://doi.org/10.1016/S0048-7333(01)00163-9

Man, T. W. Y., Lau, T., \& Chan, K. F. (2002). The competitiveness of small and medium enterprises: A conceptualization with focus on entrepreneurial competencies. Journal of Business Venturing, 17(2), 123-142. https://doi.org/10.1016/S0883-9026(00)00058-6

Martínez-López, F. J., Merigó, J. M., Gázquez-Abad, J. C., \& Ruiz-Real, J. L. (2020). Industrial marketing management: Bibliometric overview since its foundation. Industrial Marketing Management, 84, 19-38. https://doi.org/10.1016/j.indmarman.2019.07.014

Merigó, J. M., Gil-Lafuente, A. M., \& Yager, R. R. (2015). An overview of fuzzy research with bibliometric indicators. Applied Soft Computing Journal, 27, 420-433. https://doi.org/10.1016/j.asoc.2014.10.035

Merigó, J. M., Pedrycz, W., Weber, R., \& de la Sotta, C. (2018). Fifty years of Information Sciences: A bibliometric overview. Information Sciences, 432, 245-268. https://doi.org/10.1016/j.ins.2017.11.054

Merigó, J. M., \& Yang, J.-B. (2017). A bibliometric analysis of operations research and management science. Omega (United Kingdom), 73, 37-48. https://doi.org/10.1016/j.omega.2016.12.004

Naidoo, V. (2010). Firm survival through a crisis: The influence of market orientation, marketing innovation and business strategy. Industrial Marketing Management, 39(8), 1311-1320. https://doi. org/10.1016/j.indmarman.2010.02.005

Narula, R. (2002). Innovation systems and «inertia» in R\&D location: Norwegian firms and the role of systemic lock-in. Research Policy, 31(5), 795-816. https://doi.org/10.1016/S0048-7333(01)00148-2

Noci, G., \& Verganti, R. (1999). Managing «green» product innovation in small firms. $R$ and D Management, 29(1), 3-15. https://doi. org/10.1111/1467-9310.00112

OECD. (2005). Oslo Manual: Guidelines for Collecting and Interpreting Innovation Data. Paris and Luxembourg: OECD/Euro-stat.

Perrini, F. (2006). SMEs and CSR theory: Evidence and implications from an Italian perspective. Journal of Business Ethics, 67(3), 305316. https://doi.org/10.1007/s10551-006-9186-2

Porter, M. E. (1998). Competitive strategy: Techniques for analyzing industries and competitors: With a new introduction.

Radas, S., \& Božić, L. (2009). The antecedents of SME innovativeness in an emerging transition economy. Technovation, 29(6-7), 438-450. https://doi.org/10.1016/j.technovation.2008.12.002

Rey-Martí, A., Ribeiro-Soriano, D., \& Palacios-Marqués, D. (2016). A bibliometric analysis of social entrepreneurship. Journal of $\mathrm{Bu}$ siness Research, 69(5), 1651-1655. https://doi.org/10.1016/j.jbusres.2015.10.033

Rialti, R., Marzi, G., Ciappei, C., \& Busso, D. (2019). Big data and dynamic capabilities: A bibliometric analysis and systematic literature review. Management Decision, 57(8), 2052-2068. https://doi. org/10.1108/MD-07-2018-0821

Sarkodie, S. A., \& Strezov, V. (2019). A review on Environmental Kuznets Curve hypothesis using bibliometric and meta-analysis. Science of the Total Environment, 649, 128-145. https://doi.org/10.1016/j. scitotenv.2018.08.276

Shah, S. H. H., Lei, S., Ali, M., Doronin, D., \& Hussain, S. T. (2020). Prosumption: Bibliometric analysis using HistCite and VOSviewer. Kybernetes, 49(3), 1020-1045. https://doi.org/10.1108/K-12-2018-0696 
Shukla, N., Merigó, J. M., Lammers, T., \& Miranda, L. (2020). Half a century of computer methods and programs in biomedicine: A bibliometric analysis from 1970 to 2017. Computer Methods and Programs in Biomedicine, 183. https://doi.org/10.1016/j.cmpb.2019.105075

Solano Acosta, A., Herrero Crespo, Á., \& Collado Agudo, J. (2018). Effect of market orientation, network capability and entrepreneurial orientation on international performance of small and medium enterprises (SMEs). International Business Review, 27(6), 1128-1140. https://doi.org/10.1016/j.ibusrev.2018.04.004

Terziovski, M. (2010). Research notes and commentaries innovation practice and its performance implications in small and medium enterprises (SMEs) in the manufacturing sector: A resource-based view. Strategic Management Journal, 31(8), 892-902. https://doi. org/10.1002/smj.841

Torres-Ortega, R., Rialp-Criado, A., Rialp-Criado, J., \& Stoian, M.-C. (2015). How to measure born-global firms' orientation towards international markets? Revista Española de Investigación de Marketing ESIC, 19(2), 107-123.

Torugsa, N. A., O’Donohue, W., \& Hecker, R. (2012). Capabilities, Proactive CSR and Financial Performance in SMEs: Empirical Evidence from an Australian Manufacturing Industry Sector. Journal of Business Ethics, 109(4), 483-500. https://doi.org/10.1007/s10551011-1141-1

Tsai, W.-H., \& Chou, W.-C. (2009). Selecting management systems for sustainable development in SMEs: A novel hybrid model based on DEMATEL, ANP, and ZOGP. Expert Systems with Applications, $36(2$ PART 1), 1444-1458. https://doi.org/10.1016/j.eswa.2007.11.058 van Eck, N. J., \& Waltman, L. (2010). Software survey: VOSviewer, a computer program for bibliometric mapping. Scientometrics, 84(2), 523-538. https://doi.org/10.1007/s11192-009-0146-3

van Nunen, K., Li, J., Reniers, G., \& Ponnet, K. (2018). Bibliometric analysis of safety culture research. Safety Science, 108, 248-258. https://doi.org/10.1016/j.ssci.2017.08.011

Volberda, H. W., Van Den Bosch, F. A. J., \& Heij, C. V. (2013). Management innovation: Management as fertile ground for innovation. European Management Review, 10(1), 1-15. https://doi.org/10.1111/ emre. 12007

Walker, R. M., Damanpour, F., \& Devece, C. A. (2011). Management innovation and organizational performance: The mediating effect of performance management. Journal of Public Administration Research and Theory, 21(2), 367-386. https://doi.org/10.1093/jopart/ muq043

Wong, P. K., Ho, Y. P., \& Autio, E. (2005). Entrepreneurship, innovation and economic growth: Evidence from GEM data. Small Business Economics, 24(3), 335-350. https://doi.org/10.1007/s11187-005-2000-1

Yew Wong, K. (2005). Critical success factors for implementing knowledge management in small and medium enterprises. Industrial Management \& Data Systems, 105(3), 261-279. https://doi. org/10.1108/02635570510590101

Zhou, L., Wu, W.-P., \& Luo, X. (2007). Internationalization and the performance of born-global SMEs: The mediating role of social networks. Journal of International Business Studies, 38(4), 673-690. https://doi.org/10.1057/palgrave.jibs.8400282 